\title{
Lifestyle risk factors of non-communicable diseases among patients after liver transplantation - a pilot study
}

\author{
ANNA JAGIELSKA ${ }^{1, A, ~ B, ~ D, ~ E ~, ~ K R Z Y S Z T O F ~ J A N K O W S K I 2, ~ A, ~ B, ~ E, ~ K A T A R Z Y N A ~ O K R E ̨ G L I C K A ~}{ }^{1, c, D}$, \\ PAULINA SKUPIN ${ }^{1, D-F}$, ALEKSANDRA KOZŁOWSKA ${ }^{1, A, B}$, MAGDALENA DURLIK ${ }^{3, A, G}$, \\ PIOTR PRUSZCZYK ${ }^{2, A, G}$, ANETA NITSCH-OSUCH ${ }^{1, A, E, ~ G}$, OLGA TRONINA ${ }^{3, A, ~ B ~}$
}

\author{
${ }^{1}$ Department of Social Medicine and Public Health, Medical University of Warsaw, Poland \\ 2 Department of Internal Medicine and Cardiology, Medical University of Warsaw, Poland \\ ${ }^{3}$ Department of Transplant Medicine and Nephrology, Medical University of Warsaw, Poland
}

A - Study Design, B - Data Collection, C - Statistical Analysis, D - Data Interpretation, E - Manuscript Preparation, F - Literature Search, G - Funds Collection

Summary Background. Liver transplantation (LTx) is the ultimate treatment for some hepatologic patients (pts), very often observed having excessive weight gain after operation, resulting in an increased risk of non-communicable diseases (NCDs).

Objectives. The aim of the pilot study was to evaluate the chosen lifestyle risk factors of NCDs (nutritional status, intake of energy, micronutrients, cholesterol and fiber, smoking habit and physical activity) of LTx pts.

Material and methods. The pilot study group consisted of 44 pts (13 women and 31 men) of the Department of Transplant Medicine and Nephrology, Medical University of Warsaw. Anthropometric, nutritional, smoking habit and physical activity data was collected from September 2015 till May 2016.

Results. Mean body weight was $85.3 \pm 15.6 \mathrm{~kg}$, mean body mass index (BMI) $-29.1 \pm 4.5 \mathrm{~kg} / \mathrm{m}^{2}$, mean waist circumference (WC) $-101.9 \pm 12.3 \mathrm{~cm}$, mean $\%$ of total body fat $-28.8 \pm 7.9 \%$. Only ca. $16 \%$ of pts had a normal BMI. More than $90 \%$ of pts had abdominal obesity. Mean energy intake was 1,605.4 $\pm 441.6 \mathrm{kcal}$ (percentage of energy protein/total fat/carbohydrates $-18.2 \pm 3.2 \% / 34.4$ $\pm 5.8 \% / 47.1 \pm 6.0 \%$ ), cholesterol intake $264.6 \pm 100.7 \mathrm{mg}$, dietary fiber intake $17.4 \pm 5.8 \mathrm{~g}$ daily. Mean number of steps was $7,163.2$ $\pm 3,344.5$ per day, and mean daily MET was only $1.5 \pm 0.3$. Moderate physical activity lasted on average for 02:06 $\pm 01: 27$ (hh:mm). The prevalence for smoking was $23 \%$.

Conclusions. The diet of LTx pts was based on improper proportions of macronutrients. Anthropometric measurements of these patients revealed an impaired nutritional status, including metabolic obesity. The physical level of activity was insufficient. The prevalence for smoking was similar to the general Polish population. The presence of NCD risk factors among LTx pts requires the creation of interprofessional teams of health care workers.

Key words: life style, liver transplantation, risk of non-communicable diseases.

Jagielska A, Jankowski K, Okręglicka K, Skupin P, Kozłowska A, Durlik M, Pruszczyk P, Nitsch-Osuch A, Tronina O. Lifestyle risk factors of non-communicable diseases among patients after liver transplantation - a pilot study. Fam Med Prim Care Rev 2017; 19(3): 214-220, doi: https://doi.org/10.5114/fmpcr.2017.69277.

\section{Background}

Liver transplantation (LTX) is the ultimate treatment for some hepatologic patients (pts) in direct danger to life due to liver failure. At the same time, it often provides an improvement in the quality of life. Excessive weight gain after LTX is distinctive in this group. As LTx pts become free of dietary restrictions prior to surgery, they desire to recover the lost body weight due to negative energy balance, low protein intake and inadequate diet composition, which often results in overweight or obesity $[1,2]$. An increase in BMI of 119 American LTx pts from 24.5 $\pm 4.4 \mathrm{~kg} / \mathrm{m}^{2}$ to $29.0 \pm 10.6 \mathrm{~kg} / \mathrm{m}^{2}$ was observed over 12 months in 2006 [3]. Ribeiro et al. in 2014 reported excessive weight at a level of $57 \%$ in Brazilian LTx pts, with an obesity prevalence equal to $26.2 \%$ (of 42 LTx pts aged $50.1 \pm 13.1$ years), which was confirmed the same year by Silva Alves et al. when assessing the prevalence of obesity among 36 Brazilian pts up to 2 years after LTx $(29.4 \%$ with a mean waist circumference of (WC) 95.9 $\pm 15.0 \mathrm{~cm}$ ) [4, 5]. In 2007, the mean body mass index (BMI) of 18 Dutch LTx pts aged $48.0 \pm 11.8$ years was $26.6 \pm 5.0 \mathrm{~kg} / \mathrm{m}^{2}$, mean WC $96.6 \pm 16.8 \mathrm{~cm}$ and mean percentage of total body fat 26.9 $\pm 6.4 \%$ [6]. Excessive body mass (overweight and obesity) was reported for $28 \%$ of Polish LTx pts by Bulzacka in 2008 vs $58.6 \%$ in the Polish population [2, 7].

Excessive weight gain often results in cardiovascular disease (CVD) and metabolic syndrome, with a higher prevalence compared to the general population: CVD 25\%, hypertension $60-70 \%$, metabolic syndrome $44-58 \%$, type 2 diabetes mellitus 30-40\%, dyslipidemia 45-69\% [8].

Physical inactivity and excessive food intake are the main risk factors for overweight and obesity [2]. The reported nutritional mistakes in the diet of 119 American LTx pts in 2006 and in later studies were: increased percentage of energy from protein (ca. 17\%) and increased percentage of energy from fat (ca. $35 \%)[3,9,10]$. Da Silva Alves et al. reported an extremely low daily dietary fiber intake by Brazilian LTx pts [2]. These incorrect proportions of energy sources, together with the lack of physical activity (PA), should be considered as the causative factors of abdominal obesity (waist circumference and increased percentage of body fat), and thus increased BMI [3,10,11]. The implementation of PA after LTX should be recognized as a long-term goal. Currently, rehabilitation of LTx pts begins in the first few days after LTx, but unfortunately, in most cases, this is limited to rehabilitation in the hospital by two to four weeks after the op- 
eration. PA is essential for the proper functioning of the human body. Studies clearly show that regular PA during leisure time plays an important role in reducing the risk of NCD and mortality, as well as demonstrates its beneficial effects during recovery after major surgical operations, including LTx $[12,13]$. Reduced PA has been observed in numerous studies examining the behavior and the quality of life of LTx pts [4, 13-15]. A sedentary lifestyle can increase the risk of CVD and affect the rise of metabolic disorders. Patients with regular PA showed greater vitality and experience fewer restrictions on the functioning of daily life [12].

Dietary counseling and motivating appropriate eating habits or PA seem to be a necessary complement to the treatment of LTX pts and should be initiated soon after LTX and with regular follow-up [3].

Along with an increase in the number of LTX and an improved survival rate of LTx pts, long-term medical and nutritional care should be provided not only by transplantologists, but also by family medicine doctors, together with physiotherapist and dietitians/nutritionists to improve clinical output and prevent NCD in the population of LTx pts $[8,12,16,17]$.

\section{Objectives}

The aim of this pilot study was to evaluate the chosen lifestyle risk factors of NCD (nutritional status, intake of energy, macronutrients, cholesterol and fiber, smoking habits and physical activity) of Polish LTx pts.

\section{Material and methods}

The pilot study group consisted of 44 consecutive pts (13 women and 31 men) and was collected from September 2015 till May 2016 at the Department of Transplant Medicine and Nephrology, Medical University of Warsaw. The LTx was performed between 2003-2014. The inclusion criteria were LTx pts and their voluntary participation in the study.

The anthropometric measurements of weight, height, waist circumference (WC) and body composition (total body fat percentage $-\% \mathrm{TF}$ ) were performed using a validated scale (accuracy $0.1 \mathrm{~kg}$ and $0.1 \mathrm{~cm}$ ), a measuring tape (accuracy $0.1 \mathrm{~cm}$ ) and Maltron The BioScan 920-2S Multi-frequency analyzer (accuracy $0.01 \%)$. Body mass index (BMI) was assessed with the guidelines of the World Health Organization (WHO), WC - with the guidelines of the International Diabetes Federation (IDF) from 2006. $\% \mathrm{TF}>25 \%$ in men and $>30 \%$ in women indicated metabolic obesity [9, 17-20].

The dietary data was collected with 7-day dietary records of whole day food ration (WDFR). Quantitative assessment of the 298 WDFR was made using Diet 5 software. The content of the macronutrients (protein, fats, carbohydrates), percentage of total energy (\%TE), fatty acids (FA) (saturated [SFA], monounsaturated [MUFA] and polyunsaturated [PUFA], "trans", Omega 6, Omega 3), cholesterol and dietary fiber (DF) was compared with WHO recommendations: for the adult population or for CVD prevention (Table 1) [9, 17].

Energy requirement (ER) was estimated using the physical activity level (PAL) factor. The PAL assessment (duration and intensity of PA, Metabolic Equivalent of the Task (1 MET = $1 \mathrm{kcal} /$ $/ \mathrm{kg} / \mathrm{h}$ or $3.5 \mathrm{ml} \mathrm{O2} / \mathrm{kg} / \mathrm{min}$ ), number of steps [NS]) was done using the SeanseWear Armband, BodyMedia's, USA (worn 3-7 days). The range of PAL based on MET or NS is given in Table 2 [21, 22].

Statistical analysis was performed using Statistica software (W Shapiro-Wilk test, Student's t-test, an independent-samples $t$-test, Spearman's rank correlation coefficient). The results are presented as percentage (\%), for normally distributed data as mean (Xsr) and standard deviation (SD), for abnormally distributed data as median (Me) and minimum (Min) or maximum (Max). The significance level was $p<0.05$.
Table 1. WHO dietary recommendation [9]

Nutritional factor (intake as WHO recommendation \%TE or in units)

\begin{tabular}{|c|c|}
\hline Total fat & $15-30 \%$ \\
\hline SFA & $<10 \%$ \\
\hline PUFA & $6-10 \%$ \\
\hline Omega 6 FA & $5-8 \%$ \\
\hline Omega 3 FA & $1-2 \%$ \\
\hline „trans" FA & $<1 \%$ \\
\hline MUFA & $\begin{array}{l}\text { difference of total fat } \\
-(\text { SFA + PUFA + "trans") }\end{array}$ \\
\hline Carbohydrates & $55-75 \%$ \\
\hline Sugar & $<10 \%$ \\
\hline Protein & $10-15 \%$ \\
\hline Cholesterol & $\begin{array}{l}<300 \mathrm{mg} \text { (in CVD prevention } \\
<200 \mathrm{mg} \text { ) }\end{array}$ \\
\hline Dietary fiber & $25 \mathrm{~g}$ (in CVD prevention 30-45 g) \\
\hline
\end{tabular}

TE - total energy; SFA - saturated fatty acids; PUFA - polyunsaturated fatty acids; MUFA - monounsaturated fatty acids, "trans"; FA - "trans" fatty acids; CVD - cardiovascular disease.

Table 2 . The range of physical activity level based on metabolic equivalents or on number of steps per day [22]

\begin{tabular}{|l|l|l|}
\hline PAL & MET & NS per day \\
\hline Sedentary & $<3$ MET & $<5,000$ \\
\hline Low & - & $5,000-7,499$ \\
\hline Moderate & $3.0-5.9$ MET & $7,500-9,999$ \\
\hline Vigorous & $6.0-8.9$ MET & $>10,000$ \\
\hline Very vigorous & $>9$ MET & $>12,500$ \\
\hline
\end{tabular}

$\mathrm{PAL}$ - physical activity level; MET - metabolic equivalent; NS - number of steps.

\section{Results}

The pilot LTx group consisted of 44 pts ( 13 women and 31 men) aged 27-68 (avg. $51.5 \pm 11.0$ ) years, mean body weight $85.3 \pm 15.6 \mathrm{~kg}$, mean BMI $29.1 \pm 4.5 \mathrm{~kg} / \mathrm{m}^{2}$, mean WC 101.9 \pm 12.3 , mean \%TF $28.8 \pm 7.9 \%$ (Table 3). Only 13 (29.6\%) pts had returned to occupational activity after LTX.

Less than $23 \%$ pts smoked cigarettes (no statistically significant difference between genders). Only ca. $16 \%$ pts had normal BMI. More than $90 \%$ of pts had abdominal obesity, according to IDF recommendations (Table 4).

Bioelectrical impedance analysis (BIA) was performed for 43 pts. Metabolic obesity was found in $65.1 \%$ of respondents (69.2\% women and $63.3 \%$ men; no statistically significant differences according to gender).

The mean TE intake in WDFR was 1,605.4 $\pm 441.6 \mathrm{kcal}$. The estimated ER was not reached by ca. $95 \%$ of the participants, including $100 \%$ of the women. The recommended $\% \mathrm{TE}$ from protein of $<15 \%$ was reported in $11.4 \%$ of the LTx pts (no statistically significant differences according to gender), from total fat $-18.6 \%$ (41.7\% women and only $9.7 \%$ men had the recommended \%TE from total fat $<30 \% ; p=0.016$ ) and from carbohydrates - in $60.5 \%$ ( $75 \%$ women and $25.8 \%$ men had the recommended \%TE from carbohydrates $>50 \% ; p=0.003$ ). The average SFA intake was $21.8 \pm 7.7 \mathrm{~g}(12.2 \pm 2.6 \% \mathrm{TE})$. Males significantly more often exceeded the recommended \%TE from SFA $<10 \%$ ( $83.9 \%$ men vs $25 \%$ women; $p=0.002)$. The mean cholesterol intake $(264.6 \pm 100.7 \mathrm{mg})$ was within the WHO recommendation for the general population, but was too high according to CVD prevention guidelines. The sucrose consumption was in concurrence with the guidelines of $<10 \%$ TE of WDFR. The average intake of DF was $17.4 \pm 5.8 \mathrm{~g}$ (Table 6 ). Only $9.3 \%$ 
of LTx pts consumed the minimal recommended amount of $>25$

g. None of the women and only $6.5 \%$ of the men reached the recommended CVD prevention level of DF intake of $>30 \mathrm{~g}$ daily. Nutritional data is presented in Tables 5 and 6.

\begin{tabular}{|c|c|c|c|c|c|c|}
\hline \multirow[t]{2}{*}{ Parameter } & \multicolumn{2}{|c|}{ Women } & \multicolumn{2}{|c|}{ Men } & \multicolumn{2}{|c|}{ Total } \\
\hline & $n$ & $\begin{array}{l}\text { Xsr } \pm \text { SD } \\
* \text { Med (Min-Max) }\end{array}$ & $n$ & $\begin{array}{l}\text { Xsr } \pm \text { SD } \\
{ }^{*} \text { Med (Min-Max) }\end{array}$ & $n$ & $\begin{array}{l}\text { Xsr } \pm \text { SD } \\
* \text { Med (Min-Max) }\end{array}$ \\
\hline Age [years] & 13 & 45 (29-68) & 31 & $53(27-67)$ & 44 & $51.5(27-68)$ \\
\hline Weight [kg] & 13 & $73.7 \pm 11.5$ & 31 & $90.1 \pm 14.5$ & 44 & $85.3 \pm 15.6$ \\
\hline Height $[\mathrm{cm}]$ & 13 & $164.2 \pm 8.2$ & 31 & $173.8 \pm 7.2$ & 44 & $171.0 \pm 8.6$ \\
\hline $\mathrm{BMI}\left[\mathrm{kg} / \mathrm{m}^{2}\right]$ & 13 & $27.5 \pm 4.5$ & 31 & $29.8 \pm 4.4$ & 44 & $29.1 \pm 4.5$ \\
\hline$W C[\mathrm{~cm}]$ & 13 & $92.9 \pm 10.9$ & 30 & $105.8 \pm 10.9$ & 43 & $101.9 \pm 12.3$ \\
\hline TBF [\%] & 13 & $35.1 \pm 7.5$ & 30 & $26.1 \pm 6.5$ & 43 & $28.8 \pm 7.9$ \\
\hline
\end{tabular}

BMI - body mass index; WC - waist circumference; TBF - total body fat.

\begin{tabular}{|c|c|c|c|c|c|c|c|c|}
\hline \multirow[t]{3}{*}{ Measurement } & & \multirow{2}{*}{\multicolumn{2}{|c|}{\begin{tabular}{|l|} 
Women \\
1 \\
\end{tabular}}} & \multirow{2}{*}{\multicolumn{2}{|c|}{\begin{tabular}{|l|} 
Men \\
2 \\
\end{tabular}}} & \multirow{2}{*}{\multicolumn{2}{|c|}{\begin{tabular}{|l|} 
Total \\
3 \\
\end{tabular}}} & \multirow[t]{3}{*}{$P_{1,2}$} \\
\hline & & & & & & & & \\
\hline & & $n$ & $\%$ & $n$ & $\%$ & $n$ & $\%$ & \\
\hline \multicolumn{9}{|l|}{ BMI $\left[\mathrm{kg} / \mathrm{m}^{2}\right]$} \\
\hline Underweight & $17.0-18.5$ & 0 & 0.0 & 0 & 0.0 & 0 & 0.0 & - \\
\hline Normal & $18.5-24.9$ & 4 & 30.8 & 3 & 9.7 & 7 & 15.9 & 0.0810 \\
\hline Overweight & $25.0-29.9$ & 5 & 38.5 & 15 & 48.4 & 20 & 45.5 & 0.5463 \\
\hline $1^{\text {st }}$ degree of obesity & $30.0-34.9$ & 4 & 30.8 & 10 & 32.3 & 14 & 31.8 & 0.9229 \\
\hline $2^{\text {nd }}$ degree of obesity & $35.0-39.9$ & 0 & 0.0 & 3 & 9.7 & 3 & 6.8 & 0.2453 \\
\hline $3^{\text {rd }}$ degree of obesity & $\geq 40.0$ & 0 & 0.0 & 0 & 0.0 & 0 & 0.0 & - \\
\hline \multicolumn{9}{|l|}{$W C[\mathrm{~cm}]$} \\
\hline Normal & $\begin{array}{l}\text { women }<80 \mathrm{~cm} \\
\text { men }<94 \mathrm{~cm}\end{array}$ & 1 & 7.7 & 3 & 10.0 & 4 & 9.3 & 0.8109 \\
\hline Abdominal obesity & $\begin{array}{l}\text { women }>80 \mathrm{~cm} \\
\text { men }>94 \mathrm{~cm}\end{array}$ & 12 & 92.3 & 27 & 90.0 & 39 & 90.7 & 0.8114 \\
\hline
\end{tabular}

$\mathrm{BMI}$ - body mass index; WC - waist circumference.

\begin{tabular}{|c|c|c|c|c|}
\hline \multicolumn{2}{|c|}{ Macronutrient/(\%E) } & \multirow{2}{*}{$\begin{array}{l}\text { Women } n=12 \\
1,409.2 \pm 451.4\end{array}$} & \multirow{2}{*}{$\begin{array}{l}\text { Men } n=31 \\
1,681.3 \pm 420.7\end{array}$} & \multirow{2}{*}{\begin{tabular}{|l|} 
Total $n=43$ \\
$1,605.4 \pm 441.6$ \\
\end{tabular}} \\
\hline Energy [kcal] & Xsr \pm SD & & & \\
\hline \multirow[t]{2}{*}{ Protein [g] } & Me & 56.3 & 71.0 & 67.5 \\
\hline & Min-Max & $43.0-102.8$ & $45.1-141.6$ & $43.0-141.6$ \\
\hline Protein [\%E] & Xsr \pm SD & $17.9 \pm 4.0$ & $18.3 \pm 2.9$ & $18.2 \pm 3.2$ \\
\hline \multirow[t]{2}{*}{ Total fat [g] } & Me & 46.6 & 62.4 & 59.6 \\
\hline & Min-Max & $20.7-85.4$ & $34.5-134.3$ & $20.7-134.3$ \\
\hline Total fat [\%E] & $X s r \pm S D$ & $30.4 \pm 4.8$ & $35.9 \pm 5.4$ & $34.4 \pm 5.8$ \\
\hline \multirow[t]{2}{*}{ MUFA [g] } & Me & 20.8 & 25.9 & 24.3 \\
\hline & Min-Max & 7.0-38.3 & $13.8-64.0$ & 7.0-64.0 \\
\hline MUFA [\%E] & $X s r \pm S D$ & $12.3 \pm 2.7$ & $15.0 \pm 3.0$ & $14.2 \pm 3.1$ \\
\hline \multirow[t]{2}{*}{ PUFA [g] } & $\mathrm{Me}$ & 7.7 & 7.8 & 7.8 \\
\hline & Min-Max & $3.0-17.6$ & $4.7-22.1$ & $3.0-22.1$ \\
\hline \multirow[t]{2}{*}{ PUFA [\%E] } & Me & 4.8 & 4.7 & 4.7 \\
\hline & Min-Max & $3.2-8.4$ & $3.3-8.5$ & $3.2-8.5$ \\
\hline SFA [g] & $X s r \pm S D$ & $16.63 \pm 6.6$ & $23.8 \pm 7.2$ & $21.8 \pm 7.7$ \\
\hline \multirow[t]{2}{*}{ SFA [\%E] } & $\mathrm{Me}$ & 9.8 & 13.1 & 11.6 \\
\hline & Min-Max & $8.1-17.5$ & $8.8-16.7$ & $8.1-17.5$ \\
\hline \multirow[t]{2}{*}{ Cholesterol [mg] } & $\mathrm{Me}$ & 215.3 & 242.2 & 242.2 \\
\hline & Min-Max & $114.1-324.6$ & $153.0-510.0$ & $114.1-510.0$ \\
\hline \multirow[t]{2}{*}{ Carbohydrates [g] } & $\mathrm{Me}$ & 179.7 & 196.1 & 193.7 \\
\hline & Min-Max & $124.8-283.9$ & $120.6-382.7$ & $120.6-382.7$ \\
\hline
\end{tabular}




\begin{tabular}{|l|l|l|l|l|}
\hline \multicolumn{4}{|l|}{ Table 5. Macronutrient intake and percentage of energy (\%E) in the whole day food ratio (WDFR) of LTx pts } \\
\hline Macronutrient/(\%E) & Women $n=12$ & Men $n=31$ & Total $n=43$ \\
\hline Carbohydrates [\%E] & Xsr \pm SD & $51.2 \pm 3.8$ & $45.5 \pm 6.0$ & $47.1 \pm 6.0$ \\
\hline \multirow{2}{*}{ Sucrose [g] } & Me & 32.0 & 26.2 & 30.1 \\
\cline { 2 - 5 } & Min-Max & $5.8-57.1$ & $10.0-89.9$ & $5.8-89.9$ \\
\hline Sucrose [\%E] & Xsr \pm SD & $8.4 \pm 3.2$ & $7.8 \pm 3.4$ & $8.0 \pm 3.3$ \\
\hline Dietary fiber [g] & Xsr \pm SD & $16.6 \pm 5.2$ & $17.7 \pm 6.1$ & $17.4 \pm 5.8$ \\
\hline
\end{tabular}

E - energy; MUFA - monounsaturated fatty acids; PUFA - polyunsaturated fatty acids; SFA - saturated fatty acids; Xsr - mean; SD - standard deviation; Me - median; Min - minimum; Max - maximum.

\begin{tabular}{|c|c|c|c|c|c|c|c|c|}
\hline \multicolumn{2}{|l|}{ Macronutrient } & \multirow{2}{*}{\multicolumn{2}{|c|}{$\begin{array}{l}\text { Women } n=12 \\
1\end{array}$}} & \multirow{2}{*}{\multicolumn{2}{|c|}{$\begin{array}{l}\text { Men } n=31 \\
2\end{array}$}} & \multirow{2}{*}{\multicolumn{2}{|c|}{$\begin{array}{l}\text { Total } n=43 \\
3\end{array}$}} & \multirow[t]{3}{*}{$P_{1,2}$} \\
\hline & & & & & & & & \\
\hline & & $n$ & $\%$ & $n$ & $\%$ & $n$ & $\%$ & \\
\hline \multirow[t]{2}{*}{ Energy } & $<$ ER & 12 & 100.0 & 29 & 93.6 & 41 & 95.4 & 0.3675 \\
\hline & $>$ ER & 0 & 0.0 & 2 & 6.5 & 2 & 6.7 & - \\
\hline \multirow[t]{2}{*}{ Protein } & < 15\% WDFR & 3 & 25.0 & 2 & 6.5 & 5 & 11.6 & 0.0887 \\
\hline & $>15 \%$ WDFR & 9 & 75.0 & 29 & 93.5 & 38 & 88.4 & - \\
\hline \multirow[t]{2}{*}{ Total fat } & $<30 \%$ WDFR & 5 & 41.7 & 3 & 9.7 & 8 & 18.6 & 0.0156 \\
\hline & $>30 \%$ WDFR & 7 & 58.3 & 28 & 90.3 & 35 & 81.4 & - \\
\hline \multirow[t]{2}{*}{ Carbohydrates } & $<50 \%$ WDFR & 3 & 25.0 & 23 & 74.2 & 17 & 39.5 & 0.0031 \\
\hline & $>50 \%$ WDFR & 9 & 75.0 & 8 & 25.8 & 26 & 60.5 & - \\
\hline \multirow[t]{2}{*}{ Sucrose } & $<10 \%$ WDFR & 8 & 66.7 & 22 & 71.0 & 30 & 69.8 & 0.783 \\
\hline & $>10 \%$ WDFR & 4 & 33.3 & 9 & 29.0 & 13 & 30.2 & - \\
\hline \multirow[t]{2}{*}{ SFA } & $<10 \%$ WDFR & 9 & 75.0 & 5 & 16.1 & 14 & 32.6 & 0.0002 \\
\hline & $>10 \%$ WDFR & 3 & 25.0 & 26 & 83.9 & 29 & 67.4 & - \\
\hline \multirow[t]{2}{*}{ PUFA } & $>6 \%$ WDFR & 2 & 16.7 & 7 & 22.6 & 9 & 20.9 & 0.669 \\
\hline & $<6 \%$ WDFR & 10 & 83.3 & 24 & 77.4 & 34 & 79.1 & - \\
\hline \multirow[t]{2}{*}{ MUFA } & $>20 \%$ WDFR & 0 & 0.0 & 3 & 9.7 & 3 & 7.0 & 0.2639 \\
\hline & $<20 \%$ WDFR & 12 & 100.0 & 28 & 90.3 & 40 & 93.0 & - \\
\hline \multirow[t]{4}{*}{ Cholesterol } & $<200 \mathrm{mg}$ & 6 & 50.0 & 9 & 29.0 & 15 & 34.9 & 0.1957 \\
\hline & $>200 \mathrm{mg}$ & 6 & 50.0 & 22 & 71.0 & 28 & 65.1 & - \\
\hline & $<300 \mathrm{mg}$ & 11 & 91.7 & 19 & 61.3 & 30 & 69.8 & 0.0517 \\
\hline & $>300 \mathrm{mg}$ & 1 & 8.3 & 12 & 38.7 & 13 & 30.2 & - \\
\hline \multirow[t]{4}{*}{ Dietary fiber } & $>25 \mathrm{~g}$ & 1 & 8.3 & 3 & 9.7 & 4 & 9.3 & 0.8917 \\
\hline & $<25 \mathrm{~g}$ & 11 & 91.7 & 28 & 90.3 & 39 & 90.7 & - \\
\hline & $>30 \mathrm{~g}$ & 0 & 0.0 & 2 & 6.5 & 2 & 4.7 & 0.3675 \\
\hline & $<30 \mathrm{~g}$ & 12 & 100.0 & 29 & 93.6 & 41 & 95.4 & - \\
\hline
\end{tabular}

ER - energy requirement; SFA - saturated fatty acids; PUFA - polyunsaturated fatty acids; MUFA - monounsaturated fatty acids.

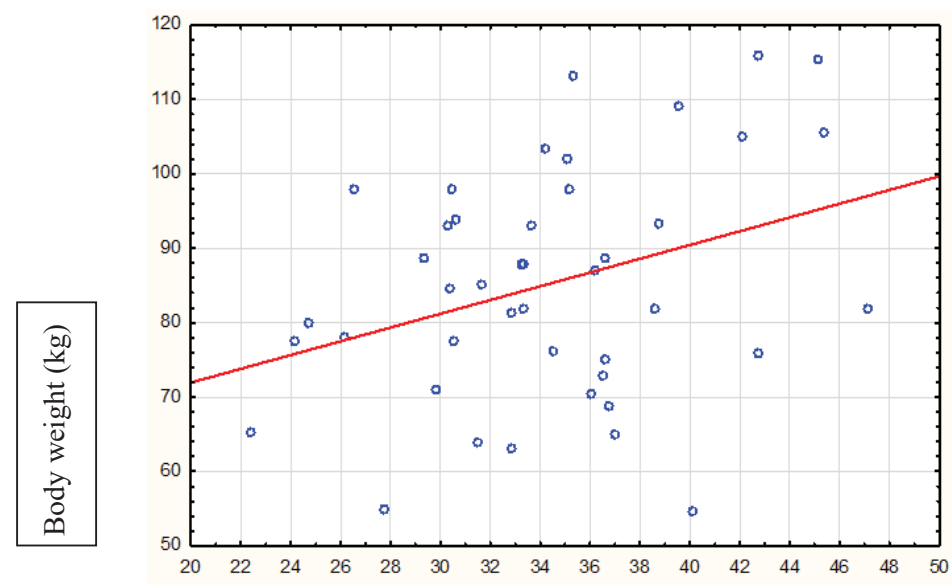

$\%$ of energy from total fat in WDFR

Figure 1. Correlation between percentage of energy from total fat in WDFR and body weight 


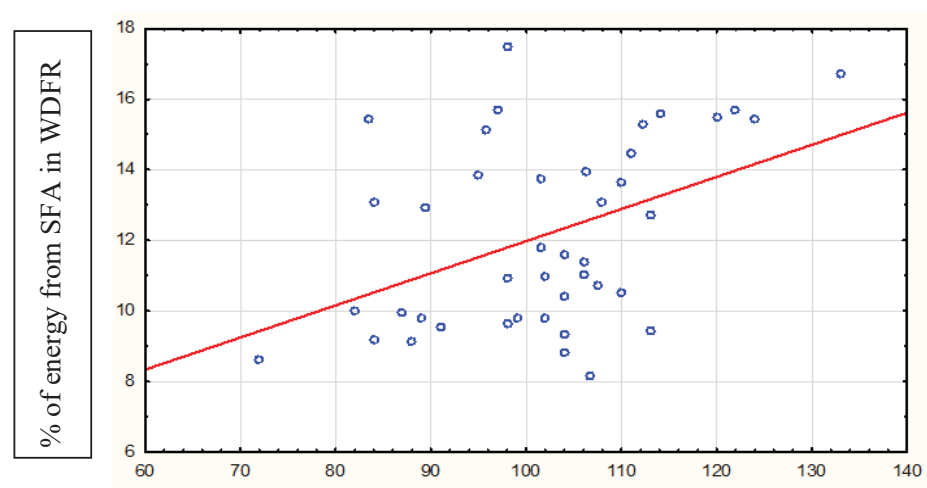

Waist circumference $(\mathrm{cm})$
Figure 2. Correlation between waist circumference and WC and percentage of energy from SFA in WDFR
A positive correlation was observed between: \%TE from total fat in WDFR and body weight $(r=0.3436 ; p=0.026)$ (Figure 1$)$; WC and \%TE from SFA in WDFR ( $r=0.4475 ; p=0.04)$ (Figure 2 ). Mean NS was 7,163.2 $\pm 3,344.5$ per day, and mean daily MET was $1.5 \pm 0.3$. Moderate PA lasted on average for 02:06 $\pm 01: 27$ (hh:mm) (Table 7). Daily PAL measured by NS qualified respondents as the group with sedentary (34.1\% of measurements) or low PA (22.7\% of measurements). The recommended level and time of PA (> 3 MET and > 45 minutes daily) was realized by $81.8 \%$ of LTx pts, from 30 to 45 minutes $-11.4 \%$ of LTx pts.

There was no statistically significant difference between genders in: PAL, PA time, recommended level and time of PA.

\begin{tabular}{|c|c|c|c|c|c|}
\hline \multicolumn{2}{|l|}{ Parameter } & $n$ & Xsr & \multicolumn{2}{|l|}{ \pm SD } \\
\hline \multicolumn{2}{|l|}{ Step number } & 44 & $7,163.2$ & \multicolumn{2}{|c|}{ $\pm 3,344.5$} \\
\hline \multicolumn{2}{|l|}{ Mean MET } & 44 & 1.5 & \multicolumn{2}{|l|}{ \pm 0.3} \\
\hline & & & Me & Min & Max \\
\hline \multirow{4}{*}{$\begin{array}{l}\text { Time of MET } \\
\text { (hh:mm) }\end{array}$} & $<3$ & 44 & 21:19 & 11:09 & $23: 22$ \\
\hline & $3-6$ & 44 & 01:51 & $00: 10$ & $06: 29$ \\
\hline & $6-9$ & 44 & 00:01 & $00: 00$ & $00: 13$ \\
\hline & $>9$ & 44 & 00:00 & 00:00 & $00: 00$ \\
\hline
\end{tabular}

\section{Discussion}

Our young/middle-aged LTx pts were characterized by excessive body weight (average body weight $85.3 \pm 15.5 \mathrm{~kg}$ and BMI $29.1 \pm 4.5 \mathrm{~kg} / \mathrm{m}^{2}$ ), which is similar to data published by Ribeiro et al., Berbke et al. and Silva Alves et al. [2, 4, 6]. The percentage of overweight and obese LTx pts in our study was higher compered to the adult Polish population or Bulzacka data [5, 7]. Incorrect WC had less than ca. 90\% participants of our study - mean WC $101.9 \pm 12.3 \mathrm{~cm}$, which increased the risk of CVD/ /NCD [23] and was reported by other researchers [2, 6, 7].

Attention was drawn by the high percentage of LTx pts with metabolic obesity in the studied group (65\%), with the average body fat percentage being $28.81 \pm 7.9 \%$, which is similar to the Dutch and Brazilian data $[4,6]$.

The average energy intake by our LTx pts was 1,605.4 $\pm 441.6 \mathrm{kcal}$, which was equal to ca. $65 \%$ of the expected energy requirements. Although these results are comparable with the results of the Ribeiro et al. study of LTx pts, in which the reported energy intake was 1,620 $\pm 457 \mathrm{kcal}$ [4], but was much lower than that reported for Italian LTx pts $(2,100 \pm 506 \mathrm{kcal})$ [23]. This might be the result of the underestimation of the quantity of products and dishes reported by the participants.

The mean percentage of energy from protein was $18 \%$ and was higher than that specified in the WHO guidelines. Although Ferreira et al. observed a similar percentage [10], other researchers reported lower levels of protein supplied through the diet (14.5-15.9\%) [6, 7].

In our study, the percentage of energy from total fat in WDFR was $34.4 \pm 5.8 \%(62.3 \pm 22.8 \mathrm{~g})$, which was comparable to the results of LTx pts published by Lunati et al. (35.5\%) and Ferreira et al. (32.7\%) [10, 23], but higher than reported by Ribeiro et al. or da Silva Alves et al. (29.1\% and $29.5 \%$, respectively) $[2,4]$. Fat intake above the recommended standards was reported more frequently among men than among women $(90.3 \%$ vs $58.3 \% ; p=0.0156$ ). In addition, we observed a typically positive correlation between the percentage of energy from total fat in the diet and body weight.

The percentage of energy from SFA reported by other authors (9.2-9.42\%), or observed in the Polish population (9.8\%), was lower than in our study $(12.2 \%)[5,14]$. It is worth noting that this exceed the WHO recommended SFA supply with diet $(<10 \%)$ and none of LTx pts has had the percentage of energy from SFA below the recommended values in prevention of CVD. The increased percentage of energy from SFA was correlated positively with waist circumference.

The percentage of energy from MUFA and PUFA ( $14.2 \%$ and $5.1 \%$, respectively) was different from that reported by Anastacio et al. (7.8\% and $8.8 \%$, respectively) [15]. Cholesterol intake in the Italian study conducted by Lunati et al. was $241.5 \pm 185$ $\mathrm{mg}$ and is comparable with the results of the study (264.6 \pm $100.7 \mathrm{mg}$ ) [23]. Lower values have been reported in Brazilian studies $(147.5-190 \mathrm{mg})[2,10,14]$.

The percentage of energy from carbohydrates in the diet of our LTx pts $(47.1 \pm 6.0 \%)$ was lower than that reported by others (48.9-57.0\%) [2, 4, 10, 23], with sucrose intake within the recommended percentage of energy $(<10 \%)$. The average intake of dietary fiber $(17.4 \pm 5.8 \mathrm{~g})$ was less than $70 \%$ of the minimum recommended amount. An insufficient intake of fiber has also been observed by other authors $[2,4,15,23]$.

In our study, the PA level was based on the number of steps, which was low and was observed for $34 \%$ LTx pts. It should be noted that we used the professional equipment measuring real physical rather than questionnaires. In other studies based on subjective questionnaires, the percentage of pts with a sedentary type of life was higher $(48.8 \%$ or $66.1 \%)[4,14]$. In our group, the recommended daily number of steps $(7,000-10,000)$ was performed by less than $16 \%$ of LTx pts. Anastacio et al. reported the mean value of the metabolic equivalent MET of LTX pts as equal to $1.35 \pm 0.17$, which is comparable with our results (mean MET $1.5 \pm 0.3$ ) [24].

The prevalence of cigarette smoking was similar to the general Polish population ( $23 \%$ vs $22 \%$ according to the WHO Report on the Global Tobacco Epidemic, 2015 Country Profile Poland) [25].

\section{Limitations of the study}

A limitation of our study was the purposive sampling related to the specificity of LTx pts from one medical center, although 
the pts were from different provinces of Poland. We examined LTx pts to obtain data about the lifestyle of this group of pts as compared to the general population, including a direct measurement of physical activity using professional devices. The cost of this equipment (ca. 1000 euro) limits their amounts and distribution to LTx pts. This study presents the results of a single measurement. As it is necessary to make observations over a period of time and take multiple measurements, we plan to repeat our measurements after 1 year from our first contact with the patients.

\section{Conclusions}

1. The diet of patients after liver transplantation was based on high protein and total fat intake, together with a low intake of carbohydrates and dietary fiber, which suggests that being overweight or obese can be the result not only of excessive calorie intake, but also from the irregular proportions of macronutrients in the diet.

2. Anthropometric measurements of patients after liver transplantation indicate an impaired nutritional status, including excessive bodyweight and metabolic obesity.

3. The physical activity level of patients after liver transplantation is insufficient.

4. The prevalence for smoking is similar to the general Polish population.

5. The presence of non-communicable risk factors among patients after liver transplantation requires the creation of inter-professional teams consisting of medical doctors, nurses, nutritionists, physiotherapists and psychologist, with the need to enlist the active participation of the patient.

Source of funding: This work was funded by the Medical University of Warsaw statutory grants of the Department of Social Medicine and Public Health, Department of Transplant Medicine and Nephrology and Department of Internal Medicine and Cardiology. Conflict of interest: The authors declare no conflict of interests.

\section{References}

1. Ferreira LG, Ferreira Martins $\mathrm{Al}, \mathrm{Cunha} \mathrm{CE}$, et al. Negative energy balance secondary to inadequate dietary intake of patients on the waiting list for liver transplantation. Nutrition 2013; 29(10): 1252-1258.

2. da Silva Alves V, Mendes RH, Pinto Kruel CD. Nutritional status, lipid profile and HOMA-IR in post-liver transplant patients. Nutr Hosp 2014; 29(5): 1154-1162.

3. Krasnoff JB, Vintro AQ, Ascher NL, et al. A randomized trial of exercise and dietary counseling after liver transplantation. Am J Transplant 2006; 6(8): 1896-905.

4. Ribeiro HS, Anastácio LR, Ferreira LG, et al. Energy expenditure and balance among long term liver recipients. Clin Nutr 2014; 33(6): 1147-1152.

5. Bulzacka M. Jakość i organizacja opieki nad pacjentami po przeszczepieniu narządów. Nursing Topics 2008; 16(1-2): 54-59 (in Polish).

6. van Ginneken BT, van den Berg-Emons RJ, Geert K, et al. Physical fitness, fatigue, and quality of life after liver transplantation. Eur J Appl Physiol 2007; 100(3): 345-353.

7. WHO. Nutrition, physical activity and obesity Poland. World Health Organization 2013 [cited 01.04.2017]. Available from URL: http:// www.euro.who.int/_data/assets/pdf_file/0020/243317/Poland-WHO-Country-Profile.pdf?ua $=1$

8. Singh S, Watt KD. Long-term medical management of the liver transplant recipient: what the primary care physician needs to know. Mayo Clin Proc 2012; 87(8): 779-790.

9. World Health Organization. Diet, nutrition and the prevention of chronic diseases: Report of a joint WHO/FAO expert consultation. Geneve: WHO; 2003.

10. Ferreira LG, Santos LF, Anastácio LR, et al. Resting energy expenditure, body composition, and dietary intake: a longitudinal study before and after liver transplantation. Transplantation 2013; 96(6): 579-585.

11. Anastacio LR, Diniz KG, Ribeiro HS, et al. Prospective evaluation of metabolic syndrome and its components among long-term liver recipients. Liver Int 2014; 34(7): 1094-1101.

12. Duffy JP, Kao K, Ko CY, et al. Long-term patient outcome and quality of life after liver transplantation: analysis of 20-year survivors. Ann Surg 2010; 252(4): 652-661.

13. Painter P, Krasnoff J, Paul SM, et al. Physical activity and Health-Related Quality of Life in liver transplant recipients. Liver Transp/ 2001; 7(3): 213-219.

14. Kotarska K, Wunsch E, Raszeja-Wyszomirska J, et al. Leisure time physical activity and health-related behaviors after liver transplantation: a prospective, single-centre study. Prz Gastroenterol 2015; 10(2): 1001-1004.

15. Anastacio LR, Ferreira LG, Ribeiro Hde S, et al. Metabolic syndrome after liver transplantation: prevalence and predictive factors. Nutrition 2011; 27(9): 931-937.

16. Kotarska K, Wunsch E, Raszeja-Wyszomirska J, et al. Female sex but not original indication affects physical activity after liver transplant: a prospective, single centre study. Exp Clin Transplant 2015; 13(3): 243-246.

17. De Luca L, Westbrook R, Tsochatzis EA. Metabolic and cardiovascular complications in the liver transplant recipient. Ann Gastroenetrol 2015; 28(2): 183-192

18. Alberti KG, Zimmet P, Shaw J. Metabolic syndrome - a new world-wide definition. A Consensus Statement from the International Diabetes Federation. Diabet Med 2006; 23(5): 469-480.

19. Suliga E. Otyłość brzuszna - metody oceny, przyczyny występowania, implikacje zdrowotne. Stud Med 2012; 27(3): 65-71 (in Polish).

20. Zeng Q, Dong SY, Sun XN, et al. Percent body fat is a better predictor of cardiovascular risk factors than body mass index. Braz $J$ Med Biol Res 2012; 45(7): 591-600.

21. Subramaniam A, McPhee M, Nagappan R. Predicting energy expenditure in sepsis: Harris-Benedict and Schofield equations versus the Weir derivation. Crit Care Resusc 2012; 14(3): 202-210.

22. Tudor-Locke C, Bassett DR. How many steps/day are enough? Preliminary pedometer indices for public health. Sports Med 2004; 34(1): $1-8$.

23. Lunati ME, Grancini V, Agnelli F, et al. Metabolic syndrome after liver transplantation: short-term prevalence and pre- and post-operative risk factors. Dig Liver Dis 2013; 45(10): 833-839.

24. Anastacio LR, Ferreira LG, de Sena Ribeiro H, et al. Body composition and overweight of liver trans plant recipients. Transplantation 2011; 92(8): 947-951.

25. WHO Report on the Global Tobacco Epidemic, 2015 Country profile Poland (2015) [cited 01.04.2017]. Available from URL: http://www. who.int/tobacco/surveillance/policy/country_profile/pol.pdf?ua = 1 . 
Tables: 7

Figures: 2

References: 25

Received: 01.05.2017

Revised: 12.06 .2017

Accepted: 09.07.2017

Address for correspondence:

Krzysztof Jankowski, MD, PhD

Klinika Chorób Wewnętrzych i Kardiologii WUM

ul. Lindleya 4

02-005 Warszawa

Polska

Tel.: +48 22 502-17-89

E-mail: krzysztofjankowski@hotmail.com 